\title{
Biopolymer Production in the Aquifer of a Groundwater Pump-and-Treat System
}

by Heather M. Knotek-Smith, Carina M. Jung, Danny Harrelson, Aimee Poda, and Anthony Bednar

PURPOSE: To establish the cause of filter clogging in the groundwater treatment system at Kirtland Air Force Base and assist in possible mitigation approaches.

BACKGROUND: The Kirtland Air Force Base (KAFB) Bulk Fuels Facility (BFF) has served as a central supply for aviation fuels since 1951. During an undetermined period from 1953 to 1999, subsurface vacuum offloading pipeline failures resulted in intermittent release of aviation gasoline (AvGas) and jet propellant fuel grades 4 (JP-4) and 8 (JP-8). AvGas contains ethylene dibromide (EDB), lead scavenger, and regulated compounds referred to as BTEX (benzene, toluene, ethylbenzene, and xylene). The resultant plume of BTEX-EDB-contaminated groundwater is being actively managed and treated. The low density BTEX (light nonaqueous phase liquid, or LNAPL) contamination is present in the vadose zone and is actively being treated using monitored natural attenuation. The EDB contamination is present in the dissolved form in the distal part of the plume under the city of Albuquerque. A pump-and-treat (P\&T) process consisting of extraction wells and the site's groundwater treatment system (GWTS) is removing this contamination.

These P\&T systems, similar to the one at KAFB-BFF, are easy to understand and implement. The GWTS system was designed according to site characterization and treatment needs. In the case of the KAFB-BFF, the treatment consisted of a sorptive removal operation using granular activated carbon (GAC) with minimal filtering or other treatment. Other components of the system provided water movement from the aquifer to the GAC and then to disposal. The aquifer tests prior to installation exhibited a specific capacity of $22.4-44.8 \mathrm{lpm}$ per foot of drawdown. The system was designed on the basis of the assumption that the aquifer would sustain pumping rates of $120 \mathrm{gpm}$ or greater. At the KAFB-BFF, secondary factors emerged that necessitated changes in the primary system designs and operating conditions.

The operation of the P\&T system resulted in water flow towards the extraction wells. The increased level and direction of water movement within the aquifer delivered the nutrients and substrates required for increased microbiological activity to the extraction wells and the GWTS. The carbon present in the previously slow-moving aquifer possibly including BTEX in the dissolved form stimulated biological activity around and in the extraction wells and at the GWTS. The microbes capable of maintaining populations in low-nutrient groundwater environments by use of BTEX compounds and other carbon sources were naturally selected for and became established. Activation of the GWTS groundwater extraction system changed this dynamic considerably by pulling the carbon sources and micronutrients into this portion of the aquifer - as it was intended to do-concentrating these substrates and free-floating microbes in and around the wells and within the filtrations system. Levels of biological activity affecting operations were the result. 

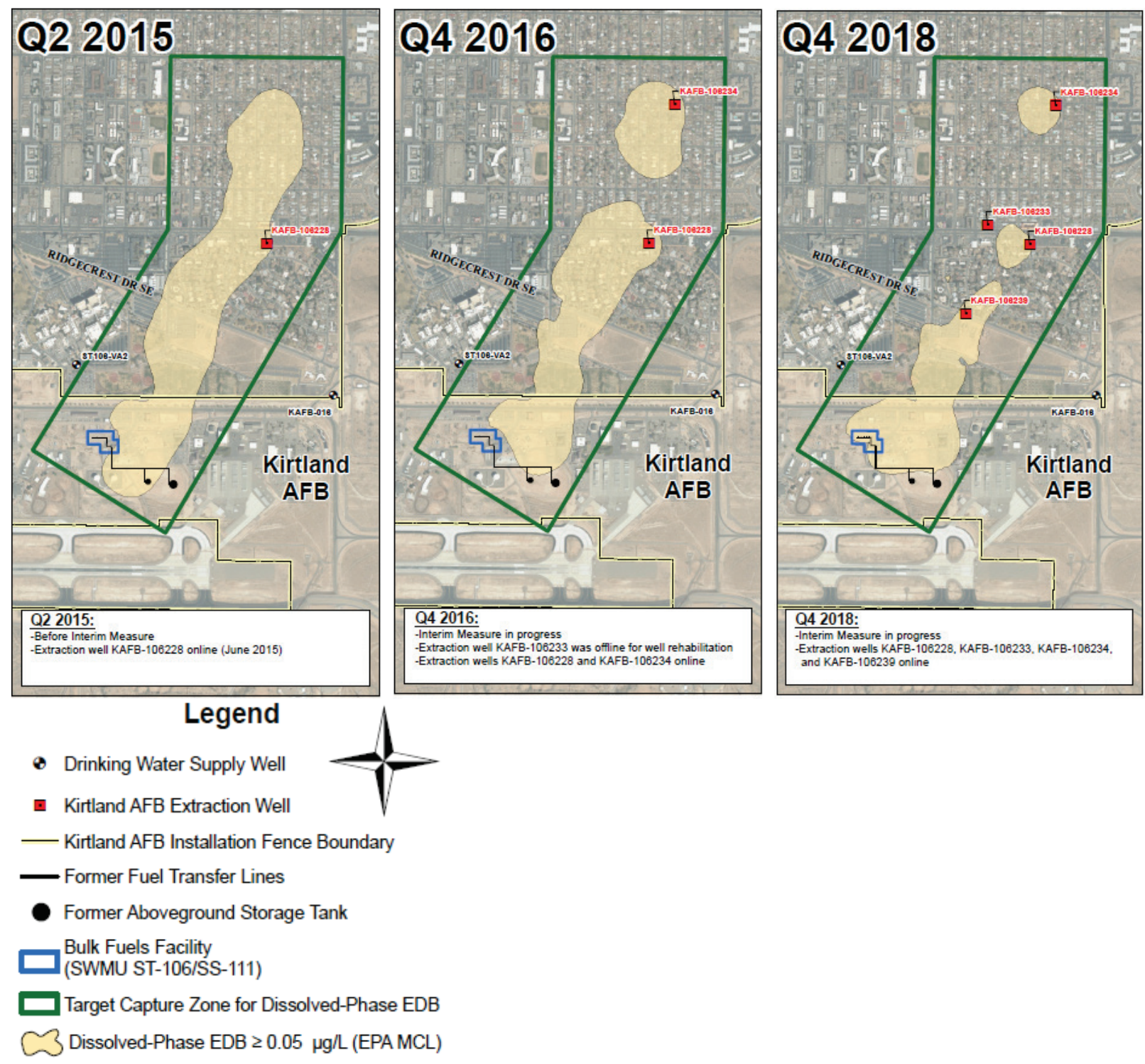

Figure 1. EDB plume contours prior to GWTS operation in 2015 (left), during the first assessment in 2016 (center), and during most recent microbial assessments in 2018 (right).

The environment in the aquifer, $450 \mathrm{ft}$ below the ground surface (bgs), changed during the first four months of operation beginning in 2016. Due to these changes, system failures occurred. Maximum flow rates at extraction well KAFB-106233 (Well 233) diminished to 76 gpm from 150 gpm. After four months of operation, the current draw required for pump operation exceeded the safety limits of the pumps, and the system automatically shut down. While the results of the perturbation of the subsurface biogeochemical system caused by the operation of the KAFB-BFF GWTS were system wide, isolation studies identified one well for which the changes were obvious and problematic. Multiple attempts to operate the pump in Well 233 proved ineffective. Electrical current draw at this site exceeded system tolerance limits within seconds to minutes after powering the pump. When this pump was replaced and inspected the, it was determined that the pump itself was undamaged and that the motor showed signs of electrical damage, possibly from extended periods of operation at or near the maximum recommended current level. The pump was 
inadequate for achieving the elevated head pressures required to achieve the desired flow rate. Filter clogging by bacterially produced organic matter was the cause of the increased head pressures.

BIOFILMS/BIOFLOC: Many bacteria produce a gel-like, organic, hydroscopic exudate classified as an extracellular polymeric substance (EPS) (Gil-Serrano et al. 1990) also known as a biopolymer (BP). Bacteria can establish and maintain biofilms (for example, EPS) on surfaces (Davies and Geesey 1995; Heilmann et al. 1996). The EPS often makes up a large fraction of the biofilm mass. Depending on bacteria type, microbial colonies can consist of $10-25 \%$ cells and $75-90 \%$ EPS as dry mass (Costerton 1999; Flemming et al. 2000; Flemming and Wingender 2010). EPS influences a number of biofilm characteristics that microbes rely on to develop and maintain communities. Some of the functions of EPS within biofilms include the following: water retention, including moisture retention in a solid matrix (Larson et al. 2012, 2016, 2019); surface adhesion and self-adhesion of cells into biofilms (Sutherland 2001); formation of protective barriers, enhanced scavenging of anions and cations from bulk liquid and surfaces, and nutrient accumulation (Laspidou and Rittmann 2002); enhanced growth rates and resistance to antibiotics and disinfectants (Goldberg 2002); greater local diversity, physical protection, and stabilization (Chen et al. 1998); and providing a framework for coordinated behavior (Bais et al. 2006). This framework includes intercellular communications to promote adaptation to rapidly changing environmental conditions (Kjelleberg and Molin 2002) such as nutrient deficient conditions (Koch et al. 2001).

Biofiltration systems established for water and wastewater treatment use microbes similar to the populations that have developed in and around the KAFB wells (Ge et al. 2016). But maintaining effective flow rates and avoiding head loss due to the production of EPS within these systems presents a challenge for the operation of these filters (Morgenroth et al. 2002). EPS can inhabit as many as 1,000 times more of the filter media void space than the bacteria that produce the EPS. This nonliving, biopolymer is the problematic material — rather than the parent bacteria that produce itin media clogging, underdrain fouling, and filter head loss (Ashraf et al. 2016). 


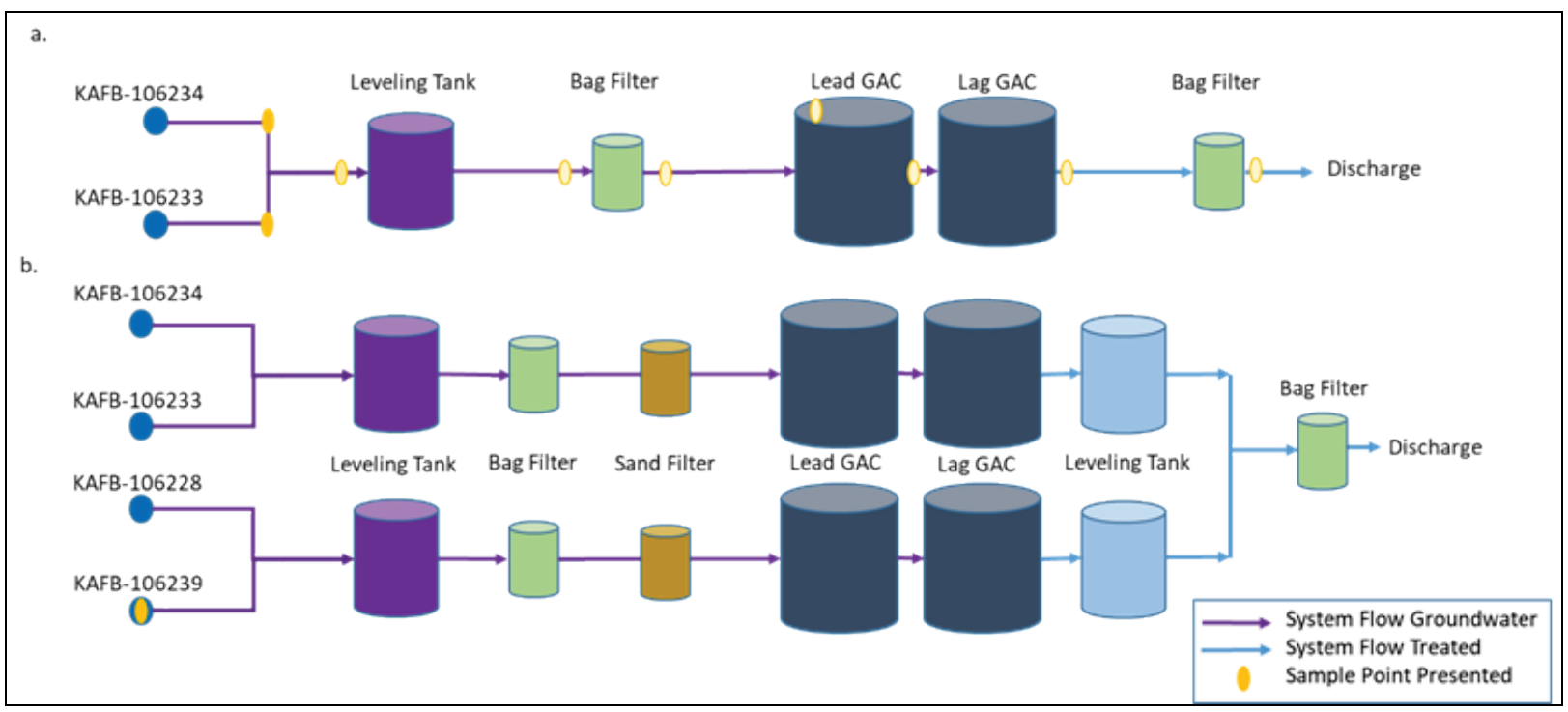

Figure 2. EDB plume contours prior to GWTS operation in 2015 (left), during the first assessment in 2016.

During the initial months of operation of the KAFB-BFF GWTS, the formation of biofilter conditions resulted in excessive EPS formation and clogging that limited the flow into and through the treatment system. Increased head loss, reduced flow rates, and fouling GAC media reduced the reactive sites and adsorption capacity of the system.

BENCH SCALE MICROCOSM STUDY: A bench-scale microcosm study conducted in 2016 determined that the microbial community responsible for the bio-fouling of the GWTS was also effective at degrading EDB contaminants (Aptim 2019). In this study waters from over 13 wells and 7 sample points within the treatment plant were inoculated into Luria Broth prepared using the modified Hungate technique (Knotek-Smith 2006) with sequential additions of BTEX components. In approximately 10\% (including the wells in which failures occurred) flocculation was noted (figure 3 , left) whereas either no floc or granular floc (figure 3, right) was noted at the other sample points. Large masses of unstructured flocs like the ones seen in the image (left) form in simple microcosms where surfaces upon which biofilms might form are absent. The materials referred to as EPS make up $90 \%$ or greater of the dry mass of these suspended, noncellular materials. The ability of indigenous microbes to use the contaminants as a carbon source for cell and biofilm material production is useful as a means of biodegrading and naturally attenuating the contamination. The abundance of these microbes has likely increased in the aquifer as a result of the three to four decades of BTEX-EDB contamination following the unintended release of fuels from the BFF. 


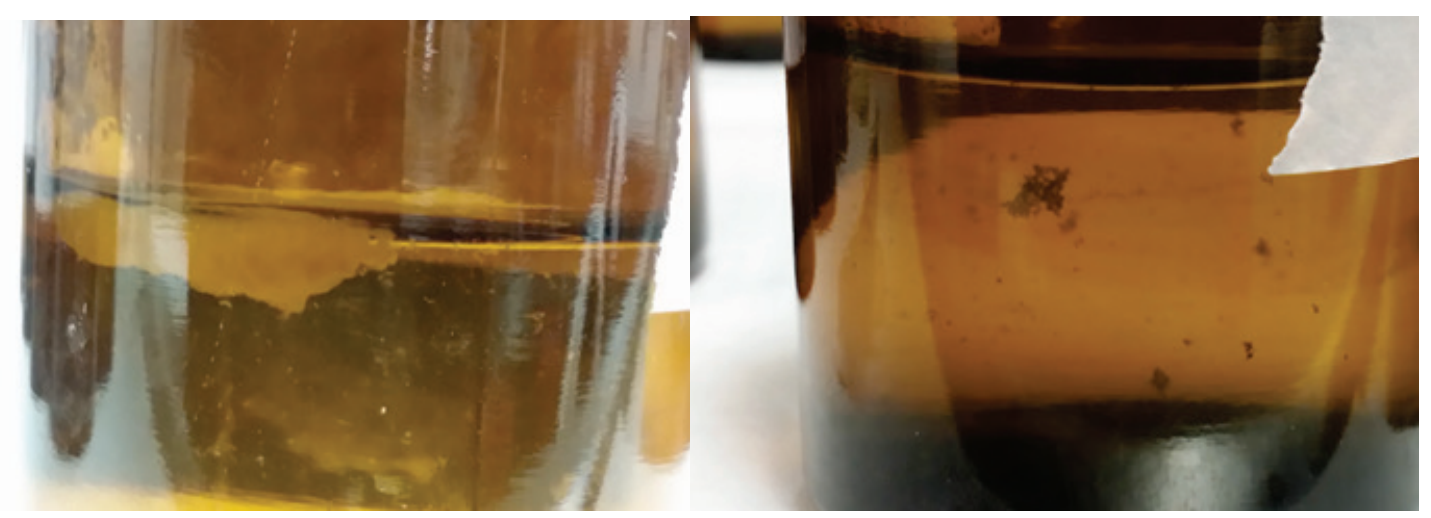

Figure 3. Comparison of floc produced in microcosm studies.

As referenced above, one of the functions of EPS is to collect and concentrate nutrients and micronutrients. By comparing the concentrations of ions required by biological systems in wells with and without floc formation, this collection and concentration can be observed.

Analysis of water collected from the well waters show elevated levels of micronutrients in wells where flocculation occurs relative to nonfloccing wells. Along with elevated levels of total solids, higher concentrations of solids and calcium (figure 4a), magnesium, potassium, and sodium (figure 4b) were measured in the water from floc-forming wells as compared to wells that did not form floc. This is a result of the presence of EPS and the natural function of EPS as a biofilm component capable of capturing these micronutrients and holding them within the biofilm for use by a bacterial community. In addition to these cations, the phosphorous levels were elevated, indicating collection and storage of anionic nutrients and phosphates (figure 4c).

Other nutrients and micronutrients such as metals necessary for cellular enzymatic functions, inorganic nutrients, and soluble organic matter ( $\mathrm{Wu} 2007)$ become incorporated into the biofilm (Fleming 2010). As a result of scavenging functions of biofilms, metal ions become concentrated in biofilms. Iron and zinc concentrations in water obtained from Well 223 were the highest of any of the wells. 


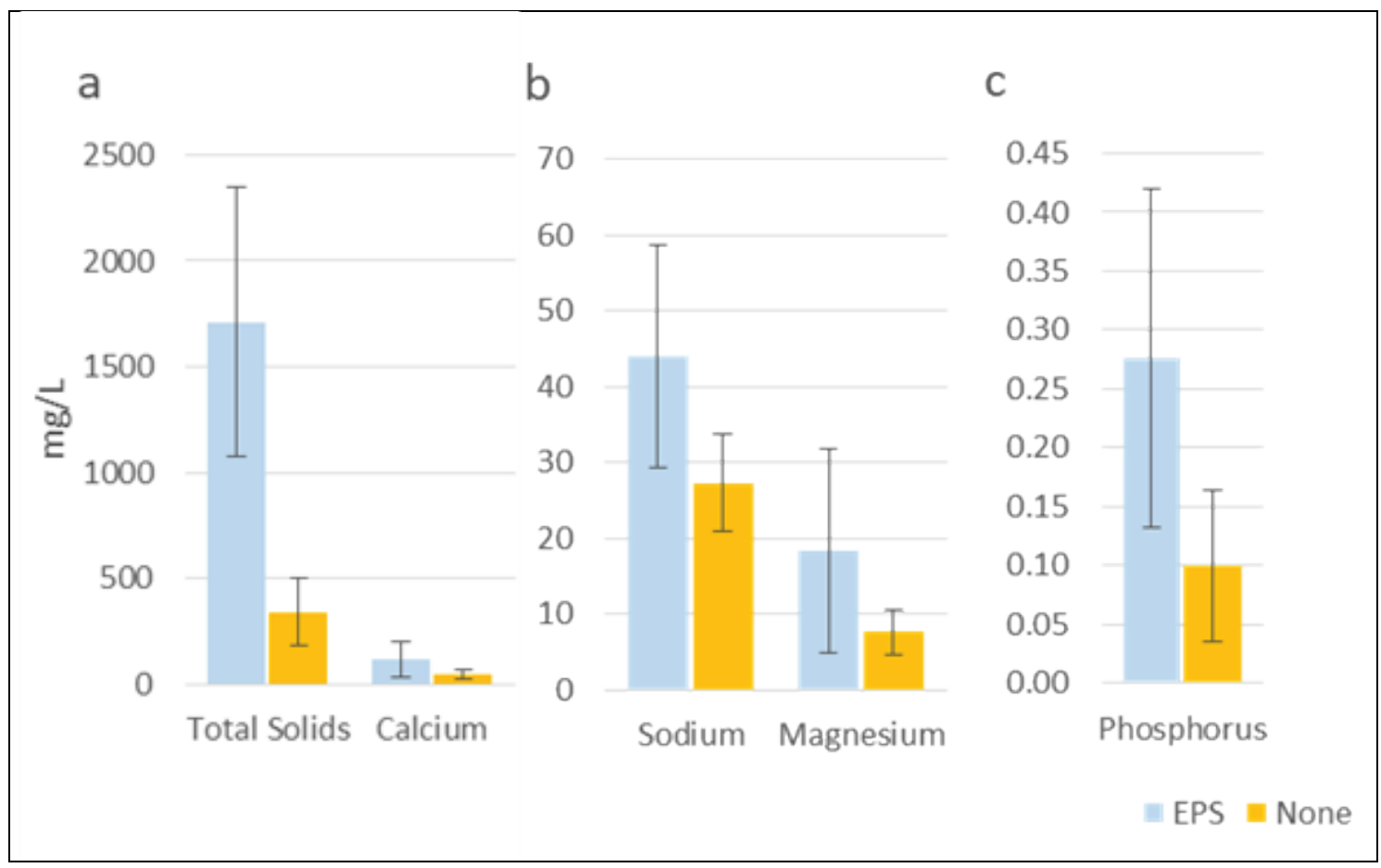

Figure 4. a-c. Well water constituents: concentrations of total solids, calcium, total organic carbon, magnesium, sodium, and phosphorus in wells exhibiting EPS flocculation and nonfloccing wells.

The elevated levels of these chemical species are indicative of EPS materials collecting and concentrating ionic nutrients for meeting microbial community needs. The high concentrations of these chemical species, relative to water from wells in which floccing is not observed, along with the elevated levels of solids, indicate the sloughing off of this material from solid support and transport within the treatment system.

The hydroscopic nature of the polymers that form a biofilm make these polymers (present as both intact biofilms and detritus from biofilms) highly effective for clogging systems. The construction of biofilms that retain water is critical to the survival of microbial communities. Within the KAFBBFF GWTS, the result is large volumes of gelatinous, pore-clogging material from a relatively small mass of EPS produced by microbes capable of utilizing the BTEX plume material as a carbon source.

The KAFB is located in a region classified as semiarid. The average annual precipitation is approximately $250 \mathrm{~mm}$ of precipitation per year (Bednar 2004). Groundwater aquifers in these geometeorological niches are static over long periods of time, with slow recharge rates and aquifer flow rates. In contrast, the subsurface flow rates established when first pumping water from the extraction wells resulted in rapid delivery of substrate to the soil around the extraction well. Microbial communities develop in these areas and produce biofilms. The hydroscopic compounds present in the biofilms act as pore-filling gel in the soil surrounding extraction wells. The plugging of these pores reduces the hydraulic conductivity of soil. The power required to maintain flow rates increases as the hydraulic conductivity decreases - and eventually may exceed the power ratings for pumping equipment, as was the case in April of 2016. When pumping rates remain constant, channeling can develop within the EPS-soil structure surrounding extraction wells. The high-water velocities within 
these channelized flow paths provide the shear force required to dislodge the biofilm material and transport the material to GWTS.

Because biofilm biopolymers are noncellular and do not contain the phospholipid bilayers present in living cells and cell detritus, the carbon-to-phosphorous ratio in biofilm solids is high. The polysaccharides that make up the bulk of biofilm materials primarily contain $\mathrm{C}^{1}, \mathrm{O}, \mathrm{H}$, and $\mathrm{N}$. Depending on the microbial community characteristics, carbon-to-phosphorous ratios between 100 and 300 are common for EPS biofilms. The high ratio of carbon to phosphorous in floc-forming wells (figure 5) indicates large amounts of EPS and relatively low numbers of cells (living or dead). Maintenance techniques intended to destroy microbial communities in the subsurface may be temporarily effective at eliminating microbial communities, but the nonliving biopolymers that make up the biofilms will persist in the absence of the microbes. Microbes present within the groundwater systems will migrate towards and into the extraction wells and re-establish communities of EPS producers as long as the environment in these areas is complementary to the establishment and growth of these communities.

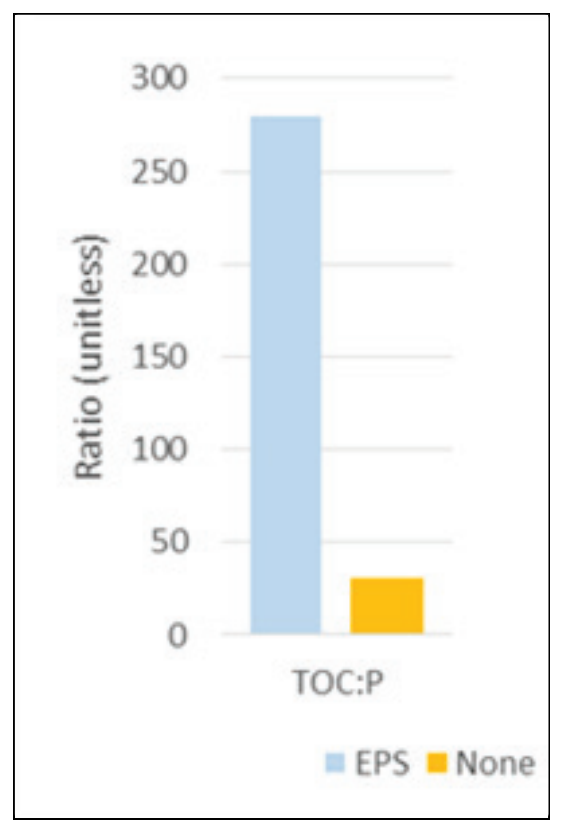

Figure 5. Ratio of carbon to phosphorus in EPS floc-forming and non-floc-forming wells.

MICROBIAL ANALYSIS OF WELL SAMPLES: Systems for DNA sequencing have become affordable and simple to operate over the last decade. Using high throughput (Illumina MiSeq) DNA sequencing techniques and phylogenetic alignments for microbial identification, the relative abundance of microbes can be estimated. Table 1 presents a subset of the microbial population at the family level as they occur within the KAFB GWTS. Sequence analysis indicates that the Rhodocyclacea and Sphingomonadales are the prominent bacterial families within the plume area. These two families represent over $70 \%$ of the bacterial community found in one of the floc-forming

1. For a full list of the spelled-out forms of the chemical elements used in this document, please refer to $U S$ Government Publishing Office Style Manual, 31st ed. (Washington, DC: US Government Publishing Office, 2016), 265, https://www.govinfo.gov/content/pkg/GPO-STYLEMANUAL-2016/pdf/GPO-STYLEMANUAL-2016.pdf. 
wells (Well 233) and were also present in samples taken from other EPS locations. These bacteria are hydrocarbon degraders. The ability of these microbes to use BTEX compounds as a carbon source was shown using controlled microcosm studies (Knotek-Smith 2003). Microcosms constructed using KAFB-BFF GWTS well waters and BTEX carbon substrates demonstrated that bacteria present in the BFF groundwater plume degrade BTEX compounds while producing large quantities of EPS. Sterilization of the wells or attempted sterilization of the groundwater will be ineffective or impossible. There is no way to overcome the natural bacterial community. Even if it were possible, the presence of these bacteria within the contaminated area is beneficial, because they provide an additional remediation capability.

The aerobic bacteria Sphingomonadales are highly represented within the subsurface bacterial consortia. This is likely due to their ability to survive in low concentrations of nutrients and to metabolize a wide variety of carbon sources (including BTEX contaminants). These bacteria have been used as an inoculant into systems with BTEX contamination in order to bioremediate and naturally attenuate contaminated groundwater. This family of bacteria is regularly isolated from environments contaminated with toxic compounds. As a tool for bioengineering, they are used for several biotechnological applications, including bioremediation and production of extracellular polymers. (Ge et al. 2016).

Table 1. Microbial communities of floc-forming wells. ( $\Delta-$ Top 2; bold text $>2 \%$ )

\begin{tabular}{|c|c|c|c|c|c|c|c|c|}
\hline \multirow[b]{2}{*}{ Phylum } & \multirow[b]{2}{*}{ Class } & \multirow[b]{2}{*}{ Order } & \multirow[b]{2}{*}{ Family } & \multicolumn{3}{|c|}{ Sampled in 2016} & \multicolumn{2}{|c|}{ Sampled in 2018} \\
\hline & & & & Well 233 & Well 234 & Well 12R & \begin{tabular}{|c|} 
Well 239 \\
(Solid)
\end{tabular} & $\begin{array}{l}\text { Well 239 } \\
\text { (Water) }\end{array}$ \\
\hline \multirow[t]{4}{*}{ Acidobacteria } & \multirow[t]{2}{*}{ Acidobacteriia } & \multirow[t]{2}{*}{ Acidobacteriales } & Acidobacteriaceae & 0.00 & 0.00 & 2.23 & 0.00 & 0.00 \\
\hline & & & Koribacteraceae & 0.00 & 0.01 & 4.24 & 0.00 & 0.00 \\
\hline & \multirow[t]{2}{*}{ Solibacteres } & Solibacterales & Solibacteraceae & 0.00 & 0.04 & $\Delta 6.97$ & 0.03 & 0.03 \\
\hline & & Solibacterales & & 0.01 & 0.27 & 2.37 & 0.00 & 0.00 \\
\hline Actinobacteria & Thermoleophilia & Solirubrobacterales & & 0.00 & 0.00 & 2.56 & 0.00 & 0.00 \\
\hline \multirow[t]{2}{*}{ Bacteroidetes } & Cytophagia & Cytophagales & Cytophagaceae & 2.45 & 0.03 & 0.00 & 0.00 & 0.00 \\
\hline & Sphingobacteriia & Sphingobacteriales & Flexibacteraceae & 0.00 & 0.00 & 0.00 & $\Delta 24.69$ & $\Delta 15.36$ \\
\hline \multirow[t]{2}{*}{ Chloroflexi } & \multirow[t]{2}{*}{ Ktedonobacteria } & Ktedonobacterales & Ktedonobacteraceae & 0.00 & 0.00 & 3.67 & 0.00 & 0.00 \\
\hline & & Thermogemmatisporales & Thermogemmatisporaceae & 0.00 & 0.00 & 3.66 & 0.01 & 0.04 \\
\hline \multirow[t]{4}{*}{ Firmicutes } & \multirow[t]{3}{*}{ Bacilli } & Bacillales & Bacillaceae & 0.00 & 0.68 & $\Delta 7.11$ & 0.03 & 0.13 \\
\hline & & & Planococcaceae & 0.04 & 0.44 & 3.45 & 0.01 & 0.05 \\
\hline & & Lactobacillales & Leuconostocaceae & 0.00 & 0.00 & 0.00 & 5.35 & $\Delta 9.06$ \\
\hline & Clostridia & Clostridiales & Clostridiaceae & 0.00 & 0.00 & 0.15 & 4.13 & 7.48 \\
\hline \multirow[t]{14}{*}{ Proteobacteria } & \multirow[t]{6}{*}{ Alphaproteobacteria } & Caulobacterales & Caulobacteraceae & 0.49 & 0.11 & 3.08 & 0.34 & 0.12 \\
\hline & & \multirow[t]{2}{*}{ Rhizobiales } & Hyphomicrobiaceae & 0.01 & 0.00 & 2.44 & 0.30 & 0.87 \\
\hline & & & Xanthobacteraceae & 0.01 & 0.00 & 0.00 & 0.22 & 2.48 \\
\hline & & \multirow[t]{2}{*}{ Rhodospirillales } & Acetobacteraceae & 0.00 & 0.00 & 3.74 & 0.06 & 0.04 \\
\hline & & & Rhodospirillaceae & 0.37 & 0.20 & 3.11 & 1.24 & 0.41 \\
\hline & & Sphingomonadales & Sphingomonadaceae & $\Delta 44.91$ & 3.68 & 2.55 & 5.27 & 4.26 \\
\hline & \multirow[t]{3}{*}{ Betaproteobacteria } & \multirow[t]{2}{*}{ Burkholderiales } & Burkholderiaceae & 0.00 & 0.01 & 3.35 & 0.56 & 1.24 \\
\hline & & & Comamonadaceae & 12.41 & 3.40 & 0.28 & 3.21 & 2.62 \\
\hline & & Rhodocyclales & Rhodocyclaceae & $\Delta 28.82$ & $\Delta 26.58$ & 0.04 & $\Delta 14.21$ & 7.10 \\
\hline & \multirow[t]{5}{*}{ Gammaproteobacteria } & \multirow[t]{2}{*}{ Chromatiales } & Chromatiaceae & 0.00 & 0.00 & 0.00 & 2.36 & 1.88 \\
\hline & & & Ectothiorhodospiraceae & 0.00 & 0.00 & 0.00 & 8.85 & 6.66 \\
\hline & & \multirow[t]{2}{*}{ Pseudomonadales } & Moraxellaceae & 0.30 & $\Delta 45.40$ & 0.06 & 0.03 & 0.08 \\
\hline & & & Pseudomonadaceae & 0.03 & 11.14 & 0.14 & 0.04 & 0.02 \\
\hline & & Xanthomonadales & Sinobacteraceae & 4.30 & 0.12 & 1.33 & 6.45 & 5.72 \\
\hline
\end{tabular}


SUMMARY: The accelerated groundwater flow in the direction of the extraction wells of the KAFB-BFF GWTS, along with the unique biogeochemical conditions associated with an aged and weathered BTEX-EDB plume, resulted in production of biofilm materials in the areas proximate to the extraction wells. This biological activity produced biofilm components that reduced the hydraulic conductivity around the extraction wells, accelerated clogging of filters, reduced contaminant removal efficiencies, and necessitated unexpected system maintenance and repair activities. The chemical constituents and microbial taxonomy present in the wells used for extraction and monitoring of the groundwater contamination explain the establishment of these conditions. Plant modifications already made, including addition of backwashable sand filters and optimized pumping schemes, will provide contaminant removal in the distal EDB plume while also enhancing natural attenuation through biodegradation in the higher-concentration comingled BTEX-EDB plume.

The unique biogeochemical properties of the system, while initially creating difficulties in KAFBBFF GWTS operation, have since resulted in an engineered treatment system superior to the initial treatment system design. The current system operational parameters incorporate the natural elements in order to engineer with nature for optimal plume abatement. By adjusting pumping rates according to changes in hydraulic conductivity and organic matter production as well as the introduction of additional filtration capabilities, the base has achieved a dual remediation approach. Combining the removal of the contamination through the designed P\&T system and the natural establishment of biological degradation in the subsurface provided the most effective remedial approach for the KAFB-BFF site.

OPERATIONAL GUIDANCE: On the basis of the findings described in this report, head pressure should be monitored, and well productivity should be determined regularly for the operations performed at the GWTS. Increases in head pressures can indicate biofouling within the GAC sorptive media. Reduced well productivity (comparisons made that account for pumping energy use) can indicate reduced hydraulic conductivity in the well area. Actions that reduce the biofouling or reduced flow conditions observed could include decreased pumping rates, biocidal well treatments, additional pre-GAC filtration, and media washing. Fluctuations in aquifer levels should also be monitored as saturation and desaturation processes within the vadose zone could lead to an increase in biological activity if vadose zone soils act as substrate sources. Finally, system operating parameters for indications of increased head loss and reduced well productivity at periods during which rapid changes in aquifer levels occur should be examined in particular.

ADDITIONAL INFORMATION: This technical note was prepared by Environmental Processes Engineering, Environmental Laboratory, US Army Engineer Research and Development Center. The study was conducted in support of the Albuquerque District Office Program. This technical note should be cited as follows:

Knotek-Smith, Heather M., Carina M. Jung, Danny Harrelson, Aimee Poda, and Anthony Bednar. 2020. Biopolymer Production in an Aquifer of a Ground Water Pump and Treat System. ERDC/EL TN-20-2. Vicksburg, MS: US Army Engineer Research and Development Center. 


\section{REFERENCES}

Aptim. 2019. Ethylene Dibromide In-situ Biodegradation Pilot Test Report, Bulk Fuels Facility Solid Waste Management Unit ST-106/SS-111, KAFB-019-0001,106.

Ashraf, M.A., S. Batool, M. Ahmad, M. Sarfraz, and W.S.A.W.M. Noor. 2016. Chapter 17 - Biopolymers as biofilters and biobarriers. In, Biopolymers and Biotech Admixtures for Eco-Efficient Construction Materials, pp. 387-420, Eds. F. Pacheco-Torgal, V. Ivanov, N. Karrak, and H. Jonkers, Woodhead Publishing, Elsevier (DOI: 10.1016/C2014-0-02075-8).

Bais, H. P., Weir, T. L., Perry, L. G., Gilroy, S. Vivanco, J. M. 2006. The role of root exudates in rhizosphere interactions with plants and other organisms. Annual Review of Plant Biology 57: 233-266. DOI: 10.1146/annurev.arplant.57.032905.105159.

Bednar, A.J., Gent, D., Gilmore, J.R., Sturgis, T., Larson, S.L. 2004. Mechanisms of Thorium Migration in a Semiarid Soil. Journal of Environmental Quality 33(6):2070-7. DOI: 10.2134/jeq2004.2070.

Chen, M. J., Zhang, Z., Bott, T. R. 1998. Direct measurement of the adhesive strength of biofilms in pipes by micromanipulation. Biotechnol Tech 12: 875-880.

Costerton, J. W. 1999 Introduction to biofilm. Int J Antimicrob Agents 11: 217-21.

Davies, D. G., Geesey, G. G. 1995 Regulation of the alginate biosynthesis gene alg C in Pseudomonas aeruginosa during biofilm development in continuous culture. Appl Environ Microbiol 61: 860867.

Flemming H-C, Wingender J, Griegbe, Mayer C. 2000. Physico-chemical properties of biofilms. In: Evans LV, editor. Biofilms: recent advances in their study and control. Amsterdam: Harwood Academic Publishers, p. 19-34.

Flemming, H-C. And Wingender, J. 2010. The biofilm matrix. Nature Reviews Microbiology 8:623-633.

Ge, S., Liu, L., Xue, Q., Yuan, Z. 2016. Effects of exogenous aerobic bacteria on methane production and biodegradation of municipal solid waster in bioreactors. Waste Management 55: 93-98.

Gil-Serrano, A., del Junco, A. S., Tejero-Mateo, P. 1990. Structure of the extracellular polysaccharide secreted by Rhizobium leguminosarum var. phaseoli CIAT 899. Carbohydrate Research 204, 103107.

Goldberg, J. 2002. Biofilms and antibiotic resistance: a genetic linkage. Trends Microbiol 10: 264-264. DOI: 10.1016/So966-842X(02)02381-8.

Heilmann, C., Gerke, C., Perdeau-Emington, F., Gotz, F. 1996. Characterization of Tn917 insertion mutants of Staphylococcus epidermidis affected in biofilm formation. Infect Immun 64: 277-282.

Kjelleberg, S., Molin, S. 2002. Is there a role for quorum sensing signals in bacterial biofilms? Curr Opin Microbiol 5: 254-258.

Knotek-Smith H.M., Deobald L.A., Ederer M., Crawford D.L. 2003 Cadmium stress studies: media development, enrichment, consortia analysis, and environmental relevance. Biometals 16 (2):251261. 
Knotek-Smith, H.M., Crawford, D.L., Möller, G., Henson, R.A., 2006 Microbial studies of a seleniumcontaminated mine site and potential for on-site remediation, $J$ Ind Microbiol Biotechnol 33:897913

Koch, B., Worm, J., Jensen, L. E., Højberg, O., Nybroe, O. 2001. Carbon limitation induces s-dependent gene expression in Pseudomonas fluorescens in soil. Appl Environ Microbiol 67: 3363-3370.

Larson, S.L., Corcoran, M.K., Gent, D.B., Butler, A.D., and Nestler, C.C. 2019. Improved levee resilience through soil application of a natural organic polymer. ERDC TR-19-6. U.S. Army Corps of Engineers, Engineer Research and Development Center, Vicksburg, MS.

Larson, S. L., Newman, J. K., Griggs, C. S., Beverly, M. and Nestler, C. 2012. Biopolymers as an alternative to petroleum-based polymers for soil modification. ERDC TR-12-8. U.S. Army Corps of Engineers, Engineer Research and Development Center, Vicksburg, MS.

Larson, S. L., Nijak, G., Jr., Corcoran, M., Lord, E., Nestler, C. 2016. Evaluation of Rhizobium tropiciderived biopolymer for erosion control of protective berms. ERDC TR-16-5. U.S. Army Corps of Engineers, Engineer Research and Development Center, Vicksburg, MS.

Laspidou, C.S., Rittmann, B.E. 2002. A unified theory for extracellular polymeric substances, soluble microbial products, and active and inert biomass. Water Research 36, 2711-2720.

More, T. T., Yadav, J. S. S., Yan, S., Tyagi, R. D., Surampalli, R. Y. 2014. Extracellular polymeric substances of bacteria and their potential environmental applications. Journal of Environmental Management 144: 1-25.

Morgenroth, E., Kommedal, R., Harremoës, P. 2002. Processes and modeling of hydrolysis of particulate organic matter in aerobic wastewater treatment - a review. Water Science and Technology 45: 2540 .

Sutherland, I. W. 2001. Microbial polysaccharides from Gram-negative bacteria. Int Dairy J 11: 663-674.

Wu, X., Alshawabkeh, A., Gent, D., Larson, S.L., Davis, J.L. (2007) Lactate Transport ion Soil in DC Fields. Journal of Geotechnical and Geoenvironmental Engineering 133(12) DOI: 10.1061/(ASCE)10900241(2007)133:12(1587).

Zhang, X. and Bishop, P. 2003. Biodegradability of biofilm extracellular polymeric substances. Chemosphere 50, 63-69.

NOTE: The contents of this technical note are not to be used for advertising, publication, or promotional purposes. Citation of trade names does not constitute an official endorsement or approval of the use of such products. 